\title{
Efficacy of Entomopathogenic Nematode, Steinernema carpocapsae and its Interaction with Beauveria bassiana against Pieris rapae L. (Lepidoptera: Pieridae) Reda, E. S. ${ }^{1}$; A. M. Sallam ${ }^{1}$; H. Y. E. Ibrahim² and S. M. E. Eid ${ }^{2}$ \\ ${ }^{1}$ Zoology Department, Faculty of Science, Mansoura University. \\ ${ }^{2}$ Plant Protection Research Institute, ARC, Dokki, Giza, Egypt.
}

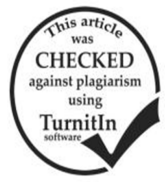

ABSTRACT

Pieris rapae L. is one of the most economically important pests of Brassicaceae causing extensive defoliation of plants. Entomopathogenic fungi and nematodes are promising biological control agents. The virulence of each of them tested alone against $4^{\text {th }}$ instar larvae and pupa of $P$. rapae. The entomopathogenic fungi, Beauveria bassiana showed efficiency against $4^{\text {th }}$ instar larvae and pupae with $\mathrm{LC}_{50}: 28.857 \times 10^{3}$ and $175.406 \times 10^{3}$ spore $/ \mathrm{ml}$, respectively. Also, the entomopathogenic nematode, Steinernema carpocapsae was revealed efficacy against $4^{\text {th }}$ instar larvae and pupae with $\mathrm{LC}_{50}: 18.148$ and $38.96 \mathrm{IJs} /$ larva and pupa, respectively. In addition, the interaction of $S$. carpocapsae with Beauveria bassiana against $P$. rapae larvae was studied. An antagonistic effect was clearly seen when $S$. carpocapsae nematode was applied immediately after the $B$. bassiana. However, the synergistic or the additive effect was seen when the application of the EPNs $12 \mathrm{~h}$ after their treatment with B. bassiana.

Keywords: Pieris rapae, Beauveria bassiana, Steinernema carpocapsae, interaction

\section{INTRODUCTION}

The cabbage butterfly, Pieris rapae L. (Lepidoptera: Pieridae) is the most common pest of cruciferous crops including cabbage, cauliflower, broccoli, brussel sprouts and others. The larvae are herbivorous causing extensive defoliation and even kill the plant. Also, it contaminates plants with large quantities of faces (Hill, 1987 and Alford, 1990).

The extensive use of synthetic insecticides resulted in many problems to the environment, human health and non-target organisms (Sifakis et al. 2011 and Fantke et al. 2012). Biological control offers many alternative agents to the traditional insecticides.

Entomopathogenic fungi offered themselves as promising biocontrol agents for insect pest control (Gottel et al., 1990 and Ferron et al., 1991) due to their good epizootic and over dependence on suitable environmental factors. In addition, they don't have to be ingested by the insect host but can invade by contact with the insect cuticle (Boucias et al., 1988).

Also, entomopathogenic nematodes especially in families Steinernematidae and heterorhabditidae can be used as biological control agents (Gaugler, 1981; Kaya, 1985 a; Poinar, 1986; Gaugler and Kaya, 1990; and Kaya and Gaugler, 1993). In spite of steinernematid and heterorhabitid nematodes can parasitize broad host range of economic insect pests, they show no mammalian pathogenicity (Gaugler and Boush, 1979; and Boemare et al., 1996). The present study was carried out to evaluate the pathogenicity of entomopathogenic fungi, Beauveria bassiana and Steinernema carpocapsae nematode as biological control agents against $P$. rapae and also studying the interaction between them in case of combined application of them.

\section{MATERIALS AND METHODS}

\section{Entomopathogenic Fungi}

Wettable powder formulation of Beauveria bassiana was provided from Insect Pathogen Production Unit (IPPU), at Plant Protection Institute, ARC, Ministry of Agriculture, Egypt. It was grown on Sabouraud dextrose yeast extract agar (SDYA) [10g/1 peptone, $40 \mathrm{~g} / 1$ dextrose, $10 \mathrm{~g} / 1$ yeast extract and $20 \mathrm{~g} / \mathrm{l}$ agar] and incubated at $25 \pm 2 \mathrm{C}^{\circ}$ and $80 \pm 5 \% \mathrm{RH}$ until further growth. The spores were harvested and counted, then the tested fungal concentrations were prepared.

Entomopathogenic Nematodes

Infective juveniles (IJs) of Steinernema carpocapsae were obtained friendly from Plant Protection Institute, ARC, Egypt.
Rearing of Galleria mellonella and nematode propagation

The greater wax moth larvae of Galleria mellonella

L. were used as a host to produce progeny of the tested nematode. The insect culture was reared in glass beakers closed with filter paper and a metal screen at $25 \pm 2{ }^{\circ} \mathrm{C}$ on an artificial diet (Ehlers, 2001). The mature females laid their eggs on the filter paper. Eggs hatched within 3-4 days and larvae were fed on the diet till reach the last instars within 56 weeks, then they were collected and inoculated with $S$. carpocapsae nematode and let nematodes to propagate inside them. Infective juveniles (IJs) were collected in White traps (White, 1927), then washed three times and stored in sterilized distilled water at $5^{\circ} \mathrm{C}$ for two weeks at the most.

Rearing of cabbage butterfly

A pure culture of $P$. rapae larvae was obtained from the farm of Faculty of Agriculture, Mansoura Univ. which is known that was free from any insecticides. The larvae reared on cabbage, Brassica oleracea var. capitata under plastic greenhouse conditions of $25 \pm 2 \mathrm{C}^{\circ}, 70 \pm 5 \mathrm{RH}$ and 14h Light: $10 \mathrm{~h}$ dark. They were let to develop to adults and gave new generations. The $4^{\text {th }}$ instar larvae of $P$. rapae were used for the laboratorial bioassays

Laboratory bioassay

1. Sterilization of $\boldsymbol{P}$. rapae tested stages and cabbage leaves

Cabbage leaves were sterilized by fast immersing in $70 \%$ alcohol then in sterilized water then $5 \%$ sodium hypochlorite for 90 seconds, then in three changes of sterile water (Clair et al., 1997). Plant leaves were dried and then used as a nutrition source.

Also, $P$. rapae $4^{\text {th }}$ instar larvae and pupae were sterilized by $1 \%$ sodium hypochlorite and then washed by sterile water.

2. Susceptibility of $P$. rapae larvae and pupae to the entomopathogenic fungi, Beauveria bassiana

Every ten sterilized pupae or $4^{\text {th }}$ instar larvae were transferred to glass jar $(10 \times 10 \times 5 \mathrm{~cm})$ containing sterilized cabbage leaf to provide larvae with nutrition, then sprayed with the fungal concentration then sealed and incubated at $22 \pm 2 \mathrm{C}^{\circ}, 70 \pm 5 \% \mathrm{RH}$., and photoperiod $16 \mathrm{~L}$ : 8D. Each concentration had three replicates and another three replicates sprayed only with water and $0.05 \%$ aqueous Tween 80 to be considered as control. In case of larval treatment, cabbage leaves were replaced by another fresh ones after the first three days of the treatment to provide nutrition source. Mortality percentage were recorded daily and the experiment continued for seven days. 
3. Susceptibility of $P$. rapae larvae and pupae to the entomopathogenic nematode, $S$. carpocapsae

Each Petri-dish lined with filter paper (Whatman No. 1) was inoculated with $2 \mathrm{ml}$ of nematode species at the tested concentrations. Ten larvae with a piece of cabbage leaf and/or ten pupae were transferred into the petri-dish, then sealed and incubated at $22 \pm 2 \mathrm{C}^{\circ}, 70 \pm 5 \mathrm{RH}$ and $14 \mathrm{~h}$ Light: $10 \mathrm{~h}$ dark. Each concentration represented by three replicates and another three as control. Mortality percentage was recorded daily along the experimental period (7 days).

Combination of $S$. carpocapsae with the entomopathogenic fungi, $B$. bassiana against $P$. rapae larvae

To determine the compatibility of $B$. bassiana with $S$. carpocapsae, ten $P$. rapae $4^{\text {th }}$ instar larvae with a piece of cabbage leaf were sprayed with $\mathrm{LC}_{50}$ of $B$. bassiana then immediately or after 12 hours, they placed onto glass jar lined with filter paper already had been inoculated with $\mathrm{LC}_{50}$ of $S$. carpocapsae and maintained under experimental conditions at $22 \pm 2{ }^{\circ} \mathrm{C}, 70 \pm 5 \% \mathrm{RH}$ and a (14: 10) L: D hour photoperiod. They daily observed and the mortality percentages were recorded. The remaining living larvae were let to pupate and continue their development.

Statistical analysis

The average of mortality percentages of both larval and pupal stages were estimated and corrected using

Table 1. Efficiency of the $B$. bassiana fungi against $4^{\text {th }}$ conditions of $22 \pm 2 \mathrm{C} 0,70 \pm 5 \% \mathrm{RH}$.

\begin{tabular}{|c|c|c|c|c|c|c|c|c|}
\hline \multicolumn{9}{|c|}{$4^{\mathrm{tn}}$ instar larvae } \\
\hline \multirow{2}{*}{ Treatment } & \multirow{2}{*}{$\begin{array}{l}\text { Conc. } \\
\text { (spore } \\
\text { /ml) }\end{array}$} & \multicolumn{4}{|c|}{$\begin{array}{c}\text { Mortality \%at indicated day } \\
\text { after treatment. }\end{array}$} & \multirow{2}{*}{$\begin{array}{c}\mathbf{L C}_{50}(\text { spore } / \mathrm{ml}) \\
\text { and confidence limits at } \\
95 \%\end{array}$} & \multirow{2}{*}{$\begin{array}{c}\mathbf{L C}_{90}(\text { spore } / \mathrm{ml}) \\
\text { and confidence limits at } \\
95 \%\end{array}$} & \multirow{2}{*}{ Slope } \\
\hline & & 1 day & 3 day & 5day & 7day & & & \\
\hline \multirow{7}{*}{ B. bassiana } & $16 \times 10^{5}$ & 0 & 16.67 & 40.00 & 46.67 & \multirow{2}{*}{$28.857 \times 10^{3}$} & \multirow{2}{*}{$31.66383 \times 10^{5}$} & \multirow{3}{*}{$\begin{array}{c}0.6281 \pm \\
0.1352\end{array}$} \\
\hline & $16 \times 10^{4}$ & $\begin{array}{l}0 \\
0\end{array}$ & 23.33 & 50.00 & 63.33 & & & \\
\hline & $\begin{array}{l}10 \times 10^{\circ} \\
16 \times 10^{\circ}\end{array}$ & $\begin{array}{l}0 \\
0\end{array}$ & $\begin{array}{l}36.6 / \\
56.67\end{array}$ & $\begin{array}{l}93.33 \\
93.33\end{array}$ & $\begin{array}{l}96.61 \\
96.67\end{array}$ & $4.398 \times 10^{3}$ & $33.9773 \times 10^{6}$ & \\
\hline & & & & & & Pupae & \multirow{3}{*}{$380.759 \times 10^{5}$} & \multirow{4}{*}{$\begin{array}{c}0.5485 \pm \\
0.1161\end{array}$} \\
\hline & $16 \times 10^{3}$ & $\begin{array}{l}0 \\
0\end{array}$ & 0 & 10.00 & $\begin{array}{l}30.00 \\
4667\end{array}$ & $175.406 \times 10^{3}$ & & \\
\hline & $16 \times 10^{5}$ & $\begin{array}{l}0 \\
0\end{array}$ & $\begin{array}{l}0 \\
0\end{array}$ & $\begin{array}{l}10.01 \\
30.00\end{array}$ & $\begin{array}{l}40.01 \\
70.00\end{array}$ & & & \\
\hline & $16 \times 10^{\circ}$ & 0 & 0 & 36.67 & 86.67 & $45.579 \times 10^{3} \quad 486.406 \times$ & $650 \times 10^{\circ} \quad 12$ & \\
\hline
\end{tabular}

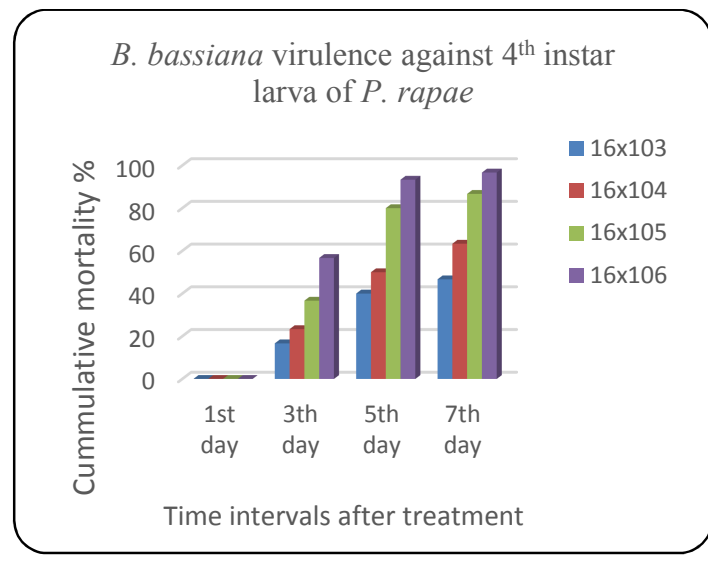

Fig. 1. Virulence of $B$. bassiana against $P$. rapae $4^{\text {th }}$ instar larvae under laboratory conditions of $22 \pm$ $2^{0} \mathrm{C}, \mathbf{7 0} \pm 5 \%$ RH.

Efficiency of the $S$. carpocapsae nematode against $4^{\text {th }}$ instar larvae and pupae of $P$. rapae

Data in Table 2 and Fig. $3 \& 4$ showed that the cumulative mortality percent increased with increasing concentrations of the tested nematodes. S. carpocapsae
Abbott's formula (1925), then, calculated according to Finney (1971). The corresponding concentration probit lines (LC-p lines) were estimated in addition to determination of $\mathrm{LC}_{50}, \mathrm{LC}_{90}$, slope values and the efficiency of tested pathogens using Sun's equation (1950).

\section{RESULTS AND DISCUSSION}

Efficiency of the $B$. bassiana fungi against $4^{\text {th }}$ instar larvae and pupae of $P$. rapae

Data in Table 1 and Fig. $1 \& 2$ showed that the cumulative mortality percent increased with increasing concentrations of the tested fungi. $B$. bassiana didn't reveal activity rather against $P$. rapae larvae nor pupae at the first day of application but the mortality percent increased with increasing the time elapsed after treatments of different concentrations of the tested fungi. This slow action due to the nature mechanism of fungi which depends on the time intervals for tissues invasion, consumption of the body of the host insect and accumulation of toxins (Ibrahim, 2012). Also, it showed more slow action against pupae this may be due to the chitinized sheath of pupa which require more time for invading it by the entomopathogenic fungi. Both of $\mathrm{LC}_{50}$ and $\mathrm{LC}_{90}$ values were obtained from probit analysis for mortality values. It was clear that larvae were more susceptible than pupae. It showed $\mathrm{LC}_{50}: 28.857 \times 10^{3}$ spore $/ \mathrm{ml}$, whereas, pupae showed $\mathrm{LC}_{50}$ of $175.406 \times 10^{3}$ spore $/ \mathrm{ml}$. instar larvae and pupae of $\boldsymbol{P}$. rapae under laboratory

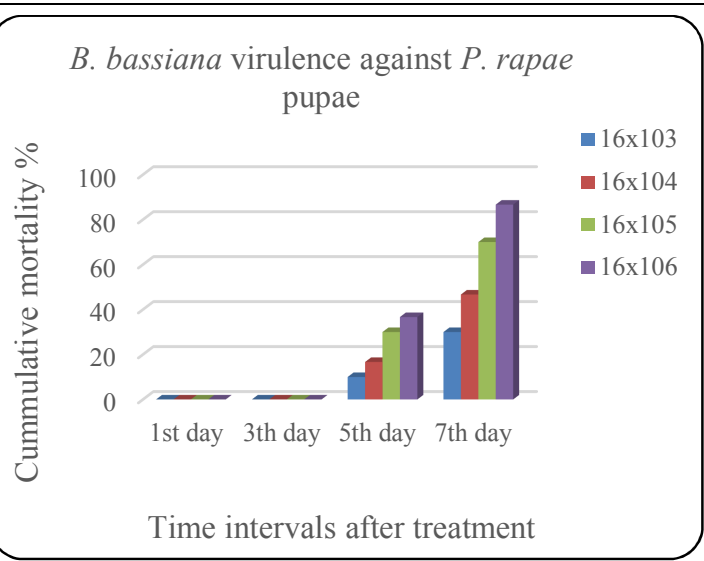

Fig. 2. Virulence of $B$. bassiana against $P$. rapae pupae under laboratory conditions of $22 \pm 2^{0} \mathrm{C}, 70 \pm 5 \%$ RH.

revealed activity within few hours after treatment of larvae and pupa. The $4^{\text {th }}$ instar larvae showed more susceptibility than pupae with $\mathrm{LC}_{50}$ : 18.148 and 38.96 IJs/larva, respectively. The infective juveniles (IJs), actively seek out hosts and penetrate the insect body 
usually through natural openings, then invade the host haemocoel releasing their symbiont bacteria, causing

septicaemia and, ultimately, killing the host (Forst and Clarke, 2002).

Table 2. Efficiency of the $S$. carpocapsae nematode against $4^{\text {th }}$ instar larvae and pupae of $P$. rapae under laboratory conditions of $22 \pm 2 \mathrm{C} 0,70 \pm 5 \%$ RH.

\begin{tabular}{|c|c|c|c|c|}
\hline \multirow{3}{*}{ Treatment } & \multirow{3}{*}{$\begin{array}{c}\text { Conc. } \\
\text { (IJs/ } \\
\text { larva) }\end{array}$} & \multicolumn{3}{|c|}{$4^{\mathrm{tn}}$ inst } \\
\hline & & \multicolumn{3}{|c|}{$\begin{array}{c}\text { Mortality \% at indicated } \\
\text { day after treatment. }\end{array}$} \\
\hline & & 1 day & 3 day & 5day \\
\hline \multirow{8}{*}{ S. carpocap } & 10 & 6.67 & 33.33 & 36.67 \\
\hline & 20 & 13.33 & 33.33 & 43.33 \\
\hline & 40 & 23.33 & 60 & 73.33 \\
\hline & 80 & 40 & 90 & 96.67 \\
\hline & a & 2000 & 3000 & 3333 \\
\hline & 50 & 23.33 & 40.00 & 53.33 \\
\hline & 75 & 40.00 & 70.00 & 76.67 \\
\hline & 100 & 36.67 & 83.33 & 96.67 \\
\hline \multirow{2}{*}{\multicolumn{5}{|c|}{$\begin{array}{l}\text { S. carpocapsae virulence against } 4^{\text {th }} \\
\text { instar larva of } P \text { rapae }\end{array}$}} \\
\hline \multirow{10}{*}{ 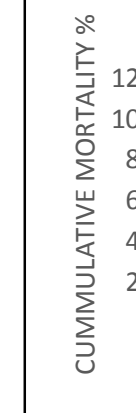 } & & & & \\
\hline & & & & $10 \mathrm{ljs} / \mathrm{larva}$ \\
\hline & & & & - $20 \mathrm{ljs} / \mathrm{larva}$ \\
\hline & & & $E$ & — 40 ljs/larva \\
\hline & & & & — $80 \mathrm{ljs} / \mathrm{larva}$ \\
\hline & & & & \\
\hline & & & & \\
\hline & & & & \\
\hline & 1st day & day & day & \\
\hline & TIME INTERV & LS AFTER & EATMENT & \\
\hline
\end{tabular}

Fig. 3. Virulence of $S$. carpocapsae against $P$. rapae $4^{\text {th }}$ instar larvae under laboratory conditions of 22 $\pm 2^{0} \mathrm{C}, \mathbf{7 0} \pm \mathbf{5 \%}$ RH.

Interaction between $B$. bassiana and $S$. carpocapsae

The present study evaluated the combined effects of the tested entomopathogenic nematode with the entomopathogenic fungi $B$. bassiana on the $4^{\text {th }}$ instar larvae of $P$. rapae. Data in Fig. 5\&6 showed that the results were entirely depended on the time interval. A simultaneous combination of both $S$. carpocapsae and B. bassiana caused marked antagonistic effect. This antagonistic effect may be due to the nature of each agent mechanism. In contrast, the

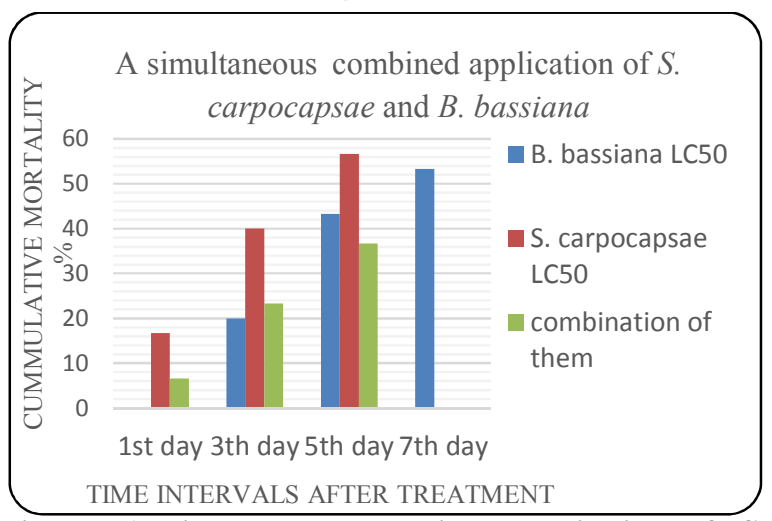

Fig. 5. A simultaneous combined application of $S$. carpocapsae and $B$. bassiana on $\mathrm{P}$, rapae $4^{\text {th }}$ instar larvae under laboratory conditions of $22 \pm 2^{0} \mathrm{C}$, $\mathbf{7 0} \pm \mathbf{5 \%}$ RH

Also, it was noticed that the treated larvae which didn't seem to be infected, they developed to the pupal stage

\begin{tabular}{|c|c|c|c|c|}
\hline \multicolumn{2}{|c|}{$\begin{array}{c}\mathrm{LC}_{50}(\mathrm{IJs} / \text { larva }) \\
\text { and confidence limits } \\
\text { at } 95 \% \\
\end{array}$} & \multicolumn{2}{|c|}{$\begin{array}{c}\mathbf{L C}_{90}(\mathrm{IJJ} / \text { larva }) \\
\text { and confidence limits } \\
\text { at } 95 \% \\
\end{array}$} & Slope \\
\hline \multicolumn{2}{|c|}{18.148} & \multicolumn{2}{|c|}{71.163} & $2.1597 \pm$ \\
\hline 12.623 & 23.729 & 48.878 & 147.494 & \\
\hline \multicolumn{5}{|c|}{ Pupae } \\
\hline \multicolumn{2}{|c|}{38.96} & \multicolumn{2}{|c|}{101.92} & $\begin{array}{c}3.0688 \pm \\
0.5856\end{array}$ \\
\hline 29.40 & 47.22 & 79.339 & 163.72 & \\
\hline
\end{tabular}

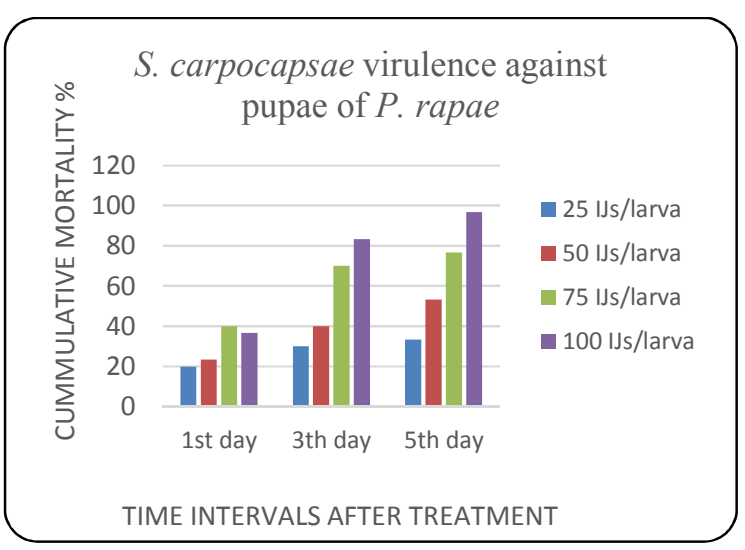

Fig. 4. Virulence of $S$. carpocapsae against $P$. rapae pupae under laboratory conditions of $22 \pm \mathbf{2}^{\mathbf{0}} \mathrm{C}$, $\mathbf{7 0} \pm \mathbf{5 \%}$ RH

combination of B. bassiana with $S$. carpocapsae after $12 \mathrm{hrs}$ caused additive and synergistic effects on the 4th instar larvae due to the stress effect caused by $B$. bassiana. There was higher efficacy of the combined application than when either the nematode or the fungus was used alone. This agreed with Abdolmaleki et al., (2017) they illustrated the additive or synergistic effects of entomopathogenic nematode $24 \mathrm{~h}$ after treatment, but the antagonistic effect was seen when the EPNs were applied immediately after the $B$. bassiana.

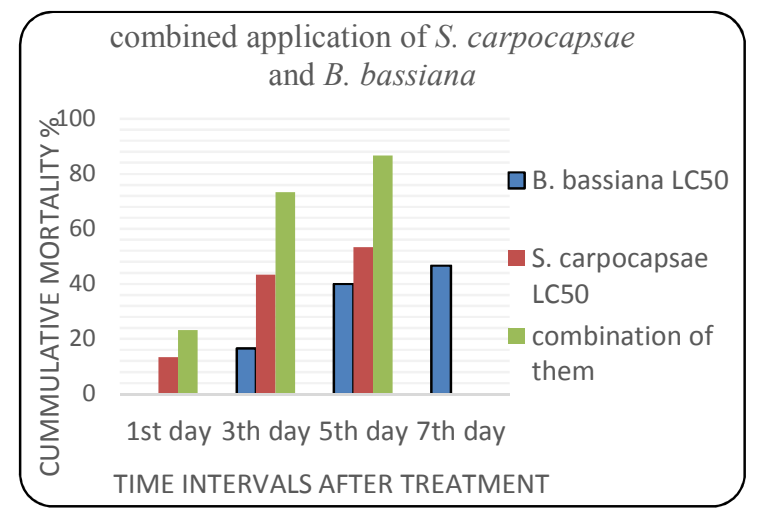

Fig. 6. combined application of $S$. carpocapsae and $B$. bassiana on $P$, rapae $4^{\text {th }}$ instar larvae after $12 \mathrm{hrs}$. under laboratory conditions of $22 \pm 2^{0} \mathrm{C}, 70 \pm 5 \% \mathrm{RH}$

but couldn't develop to the adults. This may be due to the action of one of the agents. Entomopathogenic nematodes 
have several deleterious effects on their hosts including sterility, reduced fecundity, longevity and flight activity, delayed development, or other behavioral, physiological and morphological aberrations and in some cases, rapid mortality. (Vashisth et al., 2013).

In conclusion, the combination of the entomopathogenic nematode, $S$. carpocapsae with $B$. bassiana on $P$. rapae increase their efficiency with taking into consideration the inoculation time required for fungi to establish themselves into the insect body.

\section{REFERENCES}

Abbott W S (1925). A method for computing the effectiveness an insecticide. J. Econ. Entomol., 18: 265-267.

Abdolmaleki A., H. R., Maafi, Z. t. Naseri, B. (2017). Virulence of two entomopathogenic nematodes through their interaction with Beauveria bassiana and Bacillus thuringiensis against Pieris brassicae (Lepidoptera: Pieridae). J. Crop Prot. 2017, 6 (2): 287-299.

Alford, D.V. (1990). A Text Book of Agricultural Entomology. Blackwell Science, UK, pp. 255-265.

Boemare, N. E.; Laumond, C. and Mauleon. H. 1996. The entomopathogenic nematode-bacterium complex: Biology, life cycle and vertebrate safety. Biocont. Sci. Technol. 6: 333-346.

Boucias, D. G.; Pendland, J. C. and Latge, J. P. (1988). Nonspecific factors involved in the attachment of entomopathogenic deuteromycetes to host insect cuticle. Appl. Environ. Microbial. 54(7), 1795- 1805.

Claire, V.; Lawrence, A. L. and Jacques, F. (1997). Pathogenicity of Paecilomyces fumosoroseus (Deuteromycotina: Hyphomycetes) against Bemisia argentifolii (Homoptera: Aleyrodidae) with a describtion of a bioassay method. J. Econ. Entomol. 90(3): 765- 772.

Ehlers, R. U. 2001. Mass production of entomopathogenic nematodes for plant protection. Appl. Microb. Technol. 56: 623-633.

Fantke, P., Friedrich, R. \& Jolliet, O. 2012 Health impact and damage cost assessment of pesticides in Europe. Environment International 49, 9-17.

Ferron, P.; Fargues, J. and Riba, G. (1991). Fungi as microbial insecticides against pests. In: Handbook of Applied Mycology, vol. 2. Humans, Animals and Insects. Ed. by Arora, D.K.; Ajello, L.; Mukerji, K. G. New York, USA: Marcel Dekker, pp. 665-706.
Finney D J (1971). Probit analysis. A Statistical Treatment of the Sigmoid Response Curve. 7th Ed., Cambridge Univ. Press, England.

Forst, S. and Clarke, D. 2002. Bacteria-nematode symbiosis. In: Gaugler, R. (Ed.), Entomopathogenic Nematology. CABI Publishing, London, pp. 57-77.

Gaugler, R., 1981. Biological control potential of neoaplectanid nematodes. J. Nematol., 13: 241-249.

Gaugler, R. and Boush, G.M. 1979. Nonsusceptibility rates of the entomogenous nematodes, N. carpocapsae. Envirion. Entomol., 8: 658.

Gaugler R. and Kaya H. K., 1990. Entomopathogenic nematodes in biological control. Boca Raton, Florida "CRC Press, pp: 365.

Goettel, M. S.; Poprawski, T. J.; Vandenberg, J. D.; Li, Z. and Roberts, D. W. (1990). The safety of fungal biocontrol agents to invertebrates. In: Safety of Microbial Insecticides. Ed. by Laird, M.; lacey, L. A.; Davidson, E. W.; Boca Raton, F. L, USA: CRC Press, pp. 209-231.

Hill, D. S. (1987). Agricultural insect pests of temperate regions and their control. Cambridge University Press UK.

Ibrahim, H. Y. E. 2012. Action of Some Entomopathogenic fungi on Cowpea aphid, Aphis craccivora Koch. $\mathrm{PhD}$. thesis, Fac. Sci. Mansoura Univ.

Kaya, H. K., 1985a. Entomogenous nematodes for insect control in IPM system. In M. Hoy \& D.C. Herzog [Eds.], Biological Control in Agricultural IPM systems, New York, Academic press,pp: 283-302.

Kaya, H. K. and Gaugler, R. 1993. Entomopathogenic nematodes. Ann. Rev. Entomol., 38: 181-206.

Poinar, G.O. Jr., 1986. Entomogenous nematodes. In B.D. Franz (Eds.). Biological Plants and Health protection. Fischer, Stuttgart, 95-121.

Sifakis, S., Mparmpas, M., Soldin, O. P., \& Tsatsakis, A. 2011. Pesticide Exposure and Health Related Issues in Male and Female Reproductive System. Pesticides-Formulations, Effects, Fate, 495-526.

Sun Y P (1950). Toxicity index an improved method of comparing the relative toxicity of insecticides. J. Econ. Entomol., 43: 45-53.

Vashisth, S.; Chandel, Y.S. and Sharma, P. K. (2013). Entomopathogenic nematodes-A review. Agri. Reviews, 34 (3) : 163-175, 2013.

White, G. F. 1927. A method for obtaining infective nematode larvae from cultures. Science, 66: 302303.

\section{كفاءة النيماتودا الممرضة للحشرات Steinernema carpocapsae و فطر Beauveria bassiana ,وتفاعلهما

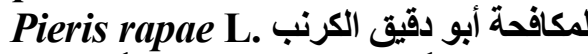

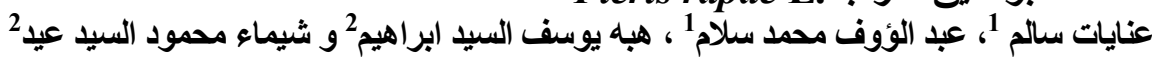

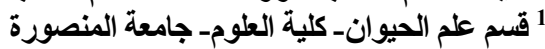

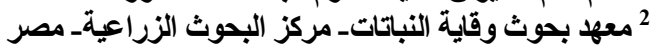

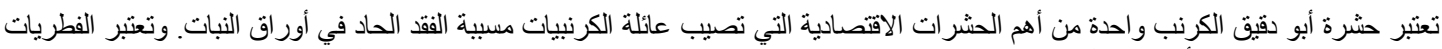

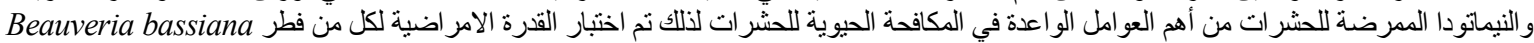
و نيماتودا Steinernema carpocapsae كل على حدى ضد الطور الر الر ابع من يرقات وعذاري ابو دقيق الكرنب ووجد ان فطر البيوفاريا يعطي كفاءة جيدة

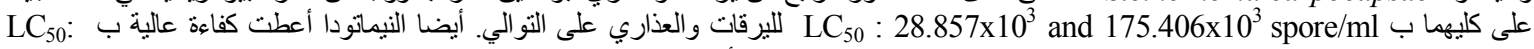
18.148 and 38.96 IJs/larva and pupa

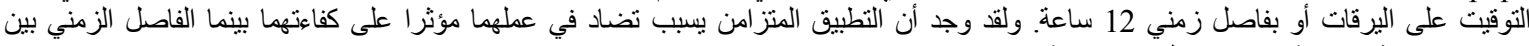
استخدامهما يعطي اضافة وزيادة في الكفاءة الابادية. 